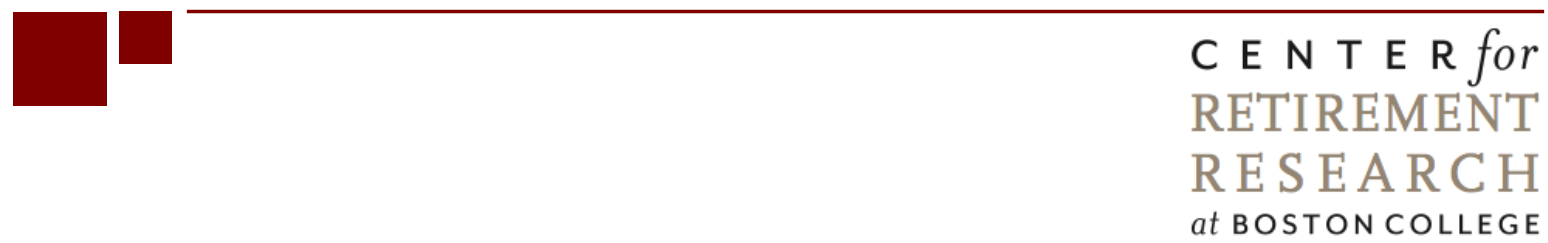

\title{
DIFFERENTIAL MORTALITY AND RETIREMENT BENEFITS IN THE HEALTH AND RETIREMENT STUDY
}

\author{
Barry P. Bosworth and Kathleen Burke \\ CRR WP 2014-4 \\ Submitted: January 2014 \\ Released: April 2014
Center for Retirement Research at Boston College
Hovey House
140 Commonwealth Avenue
Chestnut Hill, MA 02467
Tel: 617-552-1762 Fax: 617-552-0191
http://crr.bc.edu

Barry P. Bosworth is a senior fellow in economic studies at The Brookings Institution. Kathleen Burke is in the office of research at the Consumer Financial Protection Bureau. The research reported herein was pursuant to a grant from the U.S. Social Security Administration (SSA), funded as part of the Retirement Research Consortium (RRC). The findings and conclusions expressed are solely those of the authors and do not represent the views of SSA, any agency of the federal government, the RRC, The Brookings Institution, the Consumer Financial Protection Bureau, or Boston College. The authors would like to thank Kan Zhang from The Brookings Institution for computational assistance.

(C) 2014, Barry P. Bosworth and Kathleen Burke. All rights reserved. Short sections of text, not to exceed two paragraphs, may be quoted without explicit permission provided that full credit, including (C) notice, is given to the source. 


\begin{abstract}
About the Center for Retirement Research
The Center for Retirement Research at Boston College, part of a consortium that includes parallel centers at the University of Michigan and the National Bureau of Economic Research, was established in 1998 through a grant from the Social Security Administration. The Center's mission is to produce first-class research and forge a strong link between the academic community and decision-makers in the public and private sectors around an issue of critical importance to the nation's future. To achieve this mission, the Center sponsors a wide variety of research projects, transmits new findings to a broad audience, trains new scholars, and broadens access to valuable data sources.
\end{abstract}

Center for Retirement Research at Boston College

Hovey House

140 Commonwealth Avenue

Chestnut Hill, MA 02467

phone: 617-552-1762 fax: 617-552-0191

e-mail: crr@bc.edu

crr.bc.edu

Affiliated Institutions:

The Brookings Institution

Massachusetts Institute of Technology

Syracuse University

Urban Institute 


\begin{abstract}
This analysis uses data from the Health and Retirement Study (HRS) to examine the sources of variation in mortality for individuals of varying socioeconomic status. The use of the HRS allows a distinction between education and a measure of career earnings as primary determinants of socioeconomic status for men and women separately. We use those predictions of mortality to estimate the distribution of annual and lifetime Old Age, Survivors, and Disability Insurance benefits for different birth cohorts spanning the birth years from 1900 to 1950 . We find differential rates of mortality have had substantial effects in altering the distribution of lifetime benefits in favor of higher income individuals.
\end{abstract}




\section{Introduction}

The United States has been raising the age for receipt of full retirement benefits within the Social Security system as an offset to increased life expectancy. The later retirement age is seen as an important means of stabilizing the long-term costs of the Old Age, Survivors, and Disability Insurance (OASDI) program. If the retirement age were increased in proportion to life expectancy, the average length of retirement would be a constant share of the average work life; and, absent other trends, the current system's finances would be largely sustainable over future decades. ${ }^{1}$ However, research on trends in mortality has established a strong relationship between individuals' life expectancy and various measures of socioeconomic status, including income; and recent studies conclude that life expectancy is rising more rapidly for individuals in the upper portions of the earnings distribution. If gains in expected life spans are increasingly concentrated among the well-to-do, it seems unfair to ask the less affluent to bear the main burden of an aging society.

The objective of this study is to investigate the magnitude of the increase in differential mortality and its impact on the progressivity of the retirement system. Several studies have incorporated differential mortality in constructed measures of lifetime contributions and benefits; and they frequently conclude that mortality differences are sufficient to offset large portions of the progressivity that was originally built into the Social Security system. However, most of those studies were limited to the retirement portion of the OASDI program. Less account has been taken of disability and survivor benefits. As highlighted by a recent Congressional Budget Office (2006) report, most of the lifetime progressivity flows from the disability and survivor portions of the program. In contrast to the other studies, it also argues that the basic retirement program remains progressive after allowing for differing patterns of mortality.

Our analysis is focused on participants in the Health and Retirement Study (HRS), which offers several advantages for evaluating the importance of differential mortality. It includes a large sample of persons who were either retired or close to retirement and who have been followed through biennial interviews over the past 20 years; there is a large volume of information on their socioeconomic characteristics, and we have access to Social Security records on earnings and benefits for about two-thirds of the sample. Furthermore, about one-third of the participants

\footnotetext{
${ }^{1}$ Since the 1983 amendments to the Social Security Act, the average worker will make contributions sufficient to pay the full costs of his or her own retirement. That does not resolve the debt accumulated from past payments to older generations in excess of their contributions.
} 
have died. Thus, the study provides a relatively large and rich data set that we can use to explore the magnitude of differential mortality and its influence on the distribution of Social Security benefits.

\section{Literature Review}

Research on disparities in mortality by socioeconomic status (SES) was greatly stimulated by the 1975 study of Kitagawa and Hauser, who analyzed a large sample of death records from 1960 that were matched with individual records from the long form of the census of the same year. The strength of their study was the extensive information on socioeconomic characteristics - including income, education, sex, race, family status, and occupation - available from the census. It provided a basis for future studies to focus more on changes in the mortality differentials over time. There are few studies, however, that have had access to detailed mortality data combined with the type of comprehensive measures of socioeconomic status available from the census. One exception is a study by Pappas and others (1993) that replicated and updated the Kitagawa and Hauser analysis and reported that the disparities in mortality increased between 1960 and 1986, using both annual income and education as indicators of SES and a sample of 13,500 deaths.

Due to the difficulties of combining mortality data with indicators of SES, there are two main strands of U.S. research on trends in differential mortality. The first focuses on income as the primary measure of SES and relies on U.S. Social Security records to provide a measure of lifetime earnings and date of death. The second emphasizes the use of educational attainment as the SES indicator and draws on the national mortality database of the National Vital Statistics System and the U.S. Census. After a 1989 reform, U.S. death notices typically include information on educational attainment.

There are concerns with both data sources. The use of a single year's income from census records or similar source has been criticized because it includes a large transitory component. The multi-year measures of income from Social Security records would seem to overcome that objection, but substantial numbers of workers were excluded from the Social Security system in its early years. In addition, the low ceiling on taxable earnings limits the usefulness of the records prior to the 1980s; and a large proportion of married women were not in the workforce or only worked part-time, hence they have incomplete earnings records that are not representative 
of their SES. In addition, access to the records is severely restricted because of privacy concerns. Information on educational attainment is available for persons not in the labor force, and it is less influenced by health conditions that develop in middle age. It can, however, reflect significant measurement error (Boies, Rostron, and Arias, 2010). Furthermore, it is relative income, not education, that is the more direct target of policy concern.

Both methodologies report increasing differences in mortality across income classes and levels of educational attainment. In her survey of the empirical literature, Hilary Waldron (2007) argues that mortality differences by SES in the United States were generally narrowing in the first half to the $20^{\text {th }}$ century, but they have been widening since the 1960 s. Roughly similar patterns have been found for Europe, but Canada has been an exception in reporting a continuing narrowing of the differential. ${ }^{2}$

Earnings-Based Classification of Socioeconomic Status. The research based on Social Security records has the advantage of providing a relatively good measure of career income from individual earnings records. The records provide a means of distinguishing between transitory and more permanent measures of income. Waldron used average non-zero earnings of men for ages 45 to 55 from the administrative records as the measure of career earnings. The sample spanned birth cohorts from 1912 to 1941. The reliance on years with of non-zero earnings does exclude some low-wage workers with poor health and likely leads to an understatement of the mortality risk for the disabled and workers near the bottom of the income distribution. Also, she excluded women because of their sharply changing labor force participation rates over the period of analysis. She found that, if differences in rates of mortality improvement between the top and bottom half of the male career earnings distribution observed over the 1972-2001 period continue, men born in 1941 in the top half of the earnings distribution would be expected to live 5.8 years longer than men in the bottom half of the distribution, up from a difference of only 1.2 years observed for men born in 1912. The result is an extremely large increase in differential mortality.

A similar study using the same basic data source was undertaken by Duggan, Gillingham and Greenlees (2007). They applied slightly different selection criteria than Waldron by explicitly excluding the disabled and limiting the sample to retired workers with birth years

\footnotetext{
${ }^{2}$.Vallin and others (2001) and Wilkins and others (2002).
} 
between 1900 and 1942. They also find a very strong positive relationship between career income and life expectancy with a difference of two to three years between the top and bottom deciles, but they do not address the issue of a widening of the differential over time. They do report that workers who exhibit a rising trend in earnings live significantly longer; and the income-related differences in mortality between whites and blacks are most pronounced in the lower portions of the income distribution.

Education-based Classification of Socioeconomic Status. Education has been frequently used as the indicator of SES, because it is less sensitive to transitory factors than income; and as discussed above, educational attainment is included as an element of the death certificate. There have also been a substantial number of analyses since publication of the Kitagawa and Hauser study that focus on the question of whether the differentials between educational groups have been increasing. Preston and Elo (1995) reviewed a number of those studies and reported a mixed story in which the differential had clearly widened since 1960 for males, but it appeared to have declined or remained stationary for women. ${ }^{3}$

The most recent studies have been confirming an increase in the mortality differential. Meara, Richards, and Cutler (2008) examined mortality patterns from the Multiple Cause of Death data file (1990 and 2000) and the National Longitudinal Mortality Study (1981-88 and 1991-98). They restricted their analysis to non-Hispanic blacks and whites. They found that the increase in life expectancy at age 25 in both surveys was largely limited to those at the top of the educational distribution and that it was larger for men than women. Mortality differentials have declined across both the sexes and races.

Olshabsky and others (2012) used mortality data from the Multiple Cause of Death file matched with estimates of the population by age, sex, and race from the Census Bureau for the period of 1990 to 2008. They found evidence of rapidly widening mortality differentials. Life expectancy at birth actually fell for white males and females with less than 12 years of schooling, while it increased for blacks and Hispanics. It rose for all racial and sex groups with education in excess of 12 years, except for Hispanic males, and the increases were largest for those with 16 and more years of schooling.

\footnotetext{
${ }^{3}$ The major studies that they reviewed included Feldman and others (1989), Pappas and others (1993), and some of their own tabulations.
} 
Finally, area studies have matched mortality records with SES information from the census data at the level of counties and even census tracks in which the decedent lived. Thus, they compare individuals' mortality experience with the SES of the county in which they lived. A recent study by Singh and Siahpush (2006) used data from the 1980, 1990, and 2000 censuses to develop a factor-based composite index of deprivation (equivalent to SES) at the level of about 4,000 counties, which were assigned to 10 decile groups from the most- to the least-deprived counties. Corresponding mortality data by age, sex, and county were obtained for 1980-82, 1989-1991, and 1998-2000 from the national mortality database. Life expectancy at 5-year age intervals was computed from birth to age 85. Differentials in life expectancy between the $1^{\text {st }}$ and $10^{\text {th }}$ deciles showed a consistent decline by age, but they increased substantially between 1980 and 1990, and 1990 to 2000 for both men and women. For men, the differential at age 25 increased from 3 years in 1980 to 4.5 in 2000, and at age 65 it rose from 0.4 years to 1.9 years. For women, the differential increased from 0.8 to 2.8 years at age 25, and from 0 to 1.5 years at age 65. However, major migration and demographic changes mean that area-level analyses may distort the full extent of health disparities at the individual level.

Implications for the Progressivity of Social Security. There have been by now a substantial number of studies of the distributional aspects of OASDI and the influence of differential mortality, and the major issues have been identified and generally agreed on. First, the basic benefit formula of the retirement program is highly progressive with respect to point-in-time benefits, but some of the progressivity is offset on a lifetime basis by the longer expected lifetimes of high-income recipients. ${ }^{4}$ Second, the conclusions are also strongly influenced by whether disability and survivor benefits (both of which are very progressive) are included. Finally, the results vary depending on whether the progressivity is evaluated on an individual or couple basis because of the role of the spousal benefit and its interactions with the spouse's own retired-worker benefit (Smith and others, 2003 and Gustman and Steinmeier, 2001).

The Congressional Budget Office (2006) used its long-term micro-simulation model to evaluate the progressivity of the overall Social Security program (including retired workers, disabled workers, and their dependents and survivors) and concluded that the system was

\footnotetext{
${ }^{4}$ The importance of mortality also depends upon the age range of persons included in the analysis since some workers will contribute to the system, but die before they are eligible for any benefit. Others may receive a survivor's benefit based on the contributions of a deceased worker.
} 
progressive in terms of the ratio of lifetime benefits to lifetime contributions. The CBO measure was based on the income and benefits of individuals, and took account of the option to receive a spousal benefit, but it did not treat married couples as a single entity. The largest portion of the progressivity was the result of the disability and survivor programs. A similar analysis was undertaken by Steuerle, Carraso, and Cohen (2004) using the Modeling Income in the Near Term (MINT) model of the Social Security Administration. They reached very similar conclusions to those of the $\mathrm{CBO}$, that the overall system is progressive.

Goda, Shoven, and Slavov (2009) focused on the role of differential mortality, but limited their analysis to the retired-worker portion of Social Security and a set of hypothetical earnings profiles. They argue that inclusion of estimated magnitudes of differential mortality from Waldron (2007) and Cristia (2009) results in a near-complete offset of the progressivity normally shown for the retired-worker program. Harris and Sabelhaus (2005) used the CBO simulation model (discussed above) to evaluate the role of differential mortality in more detail. Starting from the projections of the Social Security Trustees as a baseline, they simulated a range of alternative assumptions about relative mortality rates. Surprisingly, they concluded that differential mortality had only a small impact on the progressivity of the overall system.

\section{Differential Mortality in the HRS}

In our analysis, we begin with the first five cohort samples of the HRS, which are summarized in Table 1. They provide a total of 30,671 respondents, spanning the birth years from the beginning of the century through 1953, and 9,914 deaths through 2011. In addition, about 65 percent of the respondents granted permission to match their information with their Social Security earnings and benefit records, but updated benefit records are available only for those who retired prior to 2008. The primary advantage of the HRS is the detailed information that is collected on respondents' socioeconomic characteristics, and the circumstance of their death is recorded from an exit interview with a relative or proxy. For those with an earnings record, we computed a measure of career earnings as the average of reported non-zero earnings, expressed in 2005 values, over the age range of $41-50 .^{5}$ Thus, we could use both career earnings

\footnotetext{
${ }^{5}$ Nominal earnings in each year were divided by the SSA average wage index with a base of 2005, eliminating the secular growth in wages. In addition, a large proportion of reported wages prior to 1980 were truncated at the taxable wage maximum. However, the earnings records contained information on the quarter in which the worker reached the taxable ceiling. We used that information to impute a wage for workers at the taxable ceiling on the
} 
and educational attainment as measures of SES. However, limiting the analysis to those with a measure of career earnings reduced the sample to 20,153 and the number of deaths to 5,413. We experimented with a first-stage estimate of career earnings for those without an earnings record (discussed below) as a means of using the full sample. ${ }^{6}$

Mortality Risks. Some simple measures of relative mortality (the annual mortality rate for a specific characteristic divided by the mortality rate for the overall group) are shown in Table $2 .^{7}$ While the surveys are conducted on a biennial basis, the information on deaths is available annually. Thus, the count of observations is very large and equal to the number of persons in the sample times the number of years that they participate prior to death. We controlled separately for gender and those ages 50-74 and ages 75 and over. Race is a distinguishing characteristic only for blacks under age 75. Mortality differs substantially by education with mortality rates of the college-educated less than half of those with less than a high school degree. Differences by quintiles of career earnings are equally marked, but a concept of household (or couple) earnings is a much more powerful discriminator than individual earnings for women. That probably reflects the intermittent work history of women in the mid-1900s, which makes earnings a poor indicator of their socioeconomic status. We defined household earnings for individuals with a spouse as the sum of the two individual career earnings divided by the square root of two. Surprisingly, the mortality rate of men over age 75 is not a smoothly declining monotonic function of income. However, the sample size is smaller for that group.

In a more formal analysis, we estimated a proportional hazard model of mortality risk that took the form:

(1) mortality $(X)=\exp \left(\beta_{i} * X_{i}\right)$,

where $\mathrm{X}$ is a vector of potential determinants of mortality risk. Among the variables we included were age and age-squared, career income (both individual and household), educational attainment, and race. We also experimented with a measure of health status as reported in the

assumption that earnings were constant throughout the year. In our sample, 50 percent had nonzero earnings in all 10 years and 14 percent were zero in all of the ten-year period.

${ }^{6}$ The lack of an earnings record is particularly common for the Aging and Health Dynamics (AHEAD) cohort of those born before 1924; yet, they account for a large number of the deaths to date. See table 1.

${ }^{7}$ A similar presentation is shown in Cristia(2009). 
prior wave as well as with whether the respondent had received disability in past waves of the survey. Both health and disability are extremely strong predictors of mortality, but we ultimately excluded them on the basis that they masked the underlying relationship with the SES indicators. Given our desire to measure changes in the degree of differential mortality, we also included the birth year to identify cohort effects.

The basic regression results for respondents with earnings records are reported in Table 3. Since we had deaths on an annual basis, the estimation interval extends from 1994 to 2009, years for which the death data seemed reasonably complete. The first panel reports the mortality rate as a log-linear function of age, household career earnings, educational attainment (college), race and birth year. It is important to remember that the sample is limited to individuals age 50 and above. The education measure is collapsed to more or less than a college degree, and black was the only significant racial indicator. ${ }^{8}$ Most noteworthy is the finding that both career earnings and education are highly significant correlates of mortality. Mortality is lower for those with a college degree and it is a declining function of career earnings. Blacks have a substantially higher mortality rate than other races. Birth year was included to measure cohort effects separate from age - and it implies that mortality is falling for later cohorts of men, but it is insignificant for women. We find no evidence of nonlinearity in the influence of age.

In the second and third panels, we include an interaction term of the birth year times the SES indicator as a measure of changing differential mortality. However, the use of two measures of SES plus an interaction term for each leads to a high degree of co-linearity. Thus, the interaction is limited to the birth year and career earnings in the second panel and the birth year and education in the third panel. In both cases, the interaction is negative and statistically significant, implying a widening of differentials by SES, and the interaction is more pronounced for women than men.

To extend the analysis beyond those with an earnings record to the full sample, we estimated a relationship for career earnings as shown in Table 4. Since the right-hand-side variables are all taken from the HRS, we can use the equation to generate predicted values for those without an earnings record; thereby obtaining a measure of individual and household

\footnotetext{
${ }^{8}$ Originally, we classified educational attainment into four groupings of less than a high school degree, high school degree, some college, and a college degree and higher. However, the largest distinction in mortality was between those with and without a college degree, and the other coefficients were not consistently monotonic in educational attainment.
} 
earnings for nearly everyone in the sample. The estimated relationship for the mortality rate for this expanded sample is reported in Table 5. The results are qualitatively similar to those for the smaller sample of those with earnings records. The evidence of increasing differential mortality is somewhat more statistically significant and more uniform across the sexes.

OASDI Benefits. Within our sample, three-fourths of the respondents $(23,142)$ reported receiving OASDI benefits at some time over the 10 survey waves from 1992 to 2010. In contrast, we have SSA benefit records for only less than half of the respondents $(13,374) .{ }^{9}$ Thus, if we use the self-reported benefits of survey respondents, we have a much larger sample of beneficiaries. Benefits are defined at the individual level and include retirement, disability and survivor benefits. The self-reported values are taken from the Rand HRS Data File. Benefits from the SSA records are after deduction of any Part B (SMI) premium payments and should correspond to the income reported in the survey. Both benefit measures are converted to 2005 values using the CPI-W. Thus, absent changes in classification (disabled, retiree, spousal or survivor beneficiaries), we expect the benefit number to be relatively constant over time.

The administrative and self-reported measures of benefits are compared by averaging the non-zero values of each across the available survey waves. We have 11,981 individuals with benefit estimates from the two sources. The simple correlation rate between the two series is 0.83 , the mean value of the self-reported values is 6 percent higher than the mean of the SSA measure of benefits and the variances differ by less than 3 percent. ${ }^{10}$ We interpret this as evidence that the self-reported values are reasonably accurate estimates of the actual benefit.

In the analysis, we utilize two different measures of benefits. The first is the selfreported individual benefit discussed above, and the second incorporates an adjustment for those individuals with a spouse: the two benefits, as with earnings, are summed and divided by the square root of 2. Both measures of benefits were first computed for each of the 10 waves, and the non-zero values are averaged over the waves in which they were reported. ${ }^{11}$ As we shall show, the two benefits are similar in amount and distribution for men, but the household-

\footnotetext{
${ }^{9}$ We have a benefit value only for those retirees whose SSA record has been updated since their retirement.

${ }^{10}$ Many of the largest differences between the two benefit series appears to occur in the first year in which the respondent receives benefits. In addition, many of the SSA records are not up to date, limiting the number of crosswave values. Finally, we made no effort to adjust for benefit changes that could be attributed to changes among the categories of disabled, retired, spousal or survivor.

${ }^{11}$ We assume that the cross-wave variation in the real value of the benefit is due to measurement error.
} 
equivalized benefits are significantly higher and more widely distributed for women. We also believe that the equivalized measure is a more accurate reflection of the individual's economic condition over their retirement years. ${ }^{12}$

We use the mortality equations in Table 5 to compute the probability of survival $\left(\mathrm{S}_{\mathrm{x}}\right.$ for each individual over the age range of 55 to 100 as

$$
S_{x}=S_{x-1} *\left(1-D_{x-1}\right)
$$

where $D_{x}$ is the expected conditional death rate at each age. Lifetime benefits are the sum of the probability of survival at a given age times the individual's fixed benefit over the interval of ages 55-100. ${ }^{13}$ As with the mortality equations, the analysis differentiates between men and women. At this stage we have not incorporated any discounting of future benefits in order to focus on the role of differences in expected mortality. The distributions of point-in-time and lifetime benefits are constructed by ranking each individual by decile of their career earnings. We computed the distribution on the basis of both individual and equivalized career earnings, but report only those based on the equivalized measure.

The basic results are reported in Table 6 and summarized in Figure 1. The distributional aspects are highlighted by showing career earnings, point-in-time benefits, and lifetime benefits in each earnings decile as a percentage of their own mean value. Thus, at the top of Table 6, male career earnings rise from 52 percent of the mean in the lowest decile to 148 percent in the top decile. There is a considerable compression of annual benefits, and the decile averages range from 78 percent of the mean in the lowest decile to 112 percent at the top. Sorting by equivalized career earning rather than benefits would, of course, narrows the range of the distribution. If we sort by benefits, the decile averages (not shown) for male benefits range from 33 percent in the lowest quintile to 174 percent at the top.

We also report their life expectancy at age 55 and the number of years they can expect to receive benefits. There is a substantial difference of life expectancy for men, ranging from 24 years in the lowest earnings decile to 34 years at the top - a difference of 10 years. The

\footnotetext{
12 For the lower-earning spouse, equivalized earnings are closer to their economic status both before and after the death of their partner.

${ }^{13}$ For those individuals with a benefit record or who began receiving benefits after they entered the survey, we have a direct measure of their age at initial retirement. For those who were receiving a benefit when they entered the study, mainly the AHEAD cohort, we assumed retirement at age 62 .
} 
distribution of benefit years is narrower, because individuals in the lower cohorts begin to receive benefits at younger ages. The differences in life expectancy widen the distribution of lifetime benefits relative to annual benefits, and it is about halfway between that of career earnings and benefits. The proportion of benefits going to the first decile is reduced by 17 percent and the proportion at the top is increased by a similar amount. The patterns of change in the distributions are more evident in the top panel of Figure 1. Benefits are still more uniformly distributed on a lifetime basis than career earnings, but the differential mortality does offset a large portion of the progressivity of the point-in-time benefit formula.

In our sample, women have a much larger variation than men in career earnings, even though we are using the adjusted measure where the spouse's earning are included for couples. However, the distribution of benefits is similar to that of men. There is also a narrower range of life expectancy across the earnings distribution, a difference of five years compared to ten for men, and the difference are even less in terms of benefit years. This is the result of a smaller degree of differential mortality for women. As with men, the distribution of benefits is wider for lifetime benefits than for annual benefits, but the magnitude of change is smaller. This is evident in the lower panel of Figure 1, where the distribution of lifetime benefits for women more closely parallels annual benefits than career earnings. ${ }^{14}$

The lower panel of Table 6 reports comparable distributions using individual-based benefits. The results for men are very similar to those based on equivalized earnings, though the level and distribution of benefits is slightly larger. The implications of the alternative perspective are more substantial for women since the average benefit is reduced by about 20 percent. The distribution is also more compressed, because women in the lower portions of the earnings distribution gain from the frequent receipt of a spousal or survivor benefit for a higherearning husband. In the top quintile, very few women qualify for a comparably high benefit. ${ }^{15}$

We can highlight the role of changing mortality, by re-computing the probability of survival under two extreme assumptions that individuals are born in either 1920 or 1940 . We performed the calculation using the mortality equations shown in Table 5 , where changes in differential mortality are measured first by the interaction of career earnings and birth year, and

\footnotetext{
${ }^{14}$ Interestingly, if individuals arrayed by their equivalized benefits, rather than career earnings, there is no evident pattern of change in life expectancy.

${ }^{15}$ The distribution of individual-based benefits is still shown using the distribution of equivalized career earnings. If we show the distribution in terms of individual career earnings, the lower two deciles of the distribution for women have zero earnings.
} 
then using the interaction of educational attainment and birth year. ${ }^{16}$ Thus, the distribution of career earnings and annual benefits remain unaffected, but life expectancy and lifetime benefits change for those born in 1940 relative to those with a birth year of 1920. The distributions of lifetime benefits and benefit years by deciles of career earnings are reported separately for men and women in Table 7. To highlight the changes by birth year, we show the values for both the 1920 and 1940 birth cohorts as a percent of the mean benefit in 1920. The top panel uses the mortality equation based on the interaction of career earnings and birth year from the middle of Table 5, and the lower panel uses the mortality equation with the interaction of educational attainment and birth year.

For men, the number of benefit years is projected to rise from 18.5 to 22.4 years between the 1920 and 1940 birth cohorts. That translates into a 21.5 percent increase in the average lifetime benefit, but the distribution is much skewed because the number of benefit years rises by only 1.6 years in the lowest decile and by 5.7 years in the $10^{\text {th }}$ decile. ${ }^{17}$ The influence of this increase in differential mortality is more evident in the top panel of Figure 2, which shows the widening gap in lifetime benefits between the two birth cohorts at higher deciles of the earnings distribution.

For women, life expectancy is rising by much smaller amounts than for men, although the level remains higher. The average increase in benefit years is only 0.6 years, and it is expected to decline for the lowest four quintiles of the earnings distribution (table 7). As a result the mortality analysis for women indicates very large changes in differential mortality. Thus, there is a large rotation of the distribution of lifetime benefits for women. The average benefit increases by only 3 percent, but the gain is 24 percent in the $10^{\text {th }}$ quintile and a loss of 10 percent in the $1^{\text {st }}$.

The estimates of differential mortality and their effects on the benefit distribution are reported in the lower panel of Table 7 using educational attainment as the basic SES measure. For men, the average increases in life expectancy and lifetime benefits are very similar to those using career earnings, but there is less evidence of any increase in differential mortality. The results for women actually indicate a reduction in the average life expectancy and show no

\footnotetext{
${ }^{16}$ In effect, all of the right-hand side variables other than birth year remain unchanged across the two birth cohorts.

${ }^{17}$ The magnitude of increase in life expectancy for the $10^{\text {th }}$ compared to the $1^{\text {st }}$ decile seems quite comparable to the results reported in Waldron (2007). She estimated the increase in life expectancy at age 65 between the top and bottom half of the career earnings distribution of men for the 1912 and 1940 birth cohorts as 5 and 1.3 years respectively.
} 
indication of any increase in differential mortality. The difference in the results based on career earnings and educational attainment are surprising. To some extent, they reflect the fact that career earnings had a stronger and more consistent influence in the mortality equations of Table 5 , and we did use a very simplified categorical variable for educational attainment - achievement of a college degree - because distinguishing among lower levels of education appeared to have no significant effect. However, the measure of educational attainment has the advantage of not requiring any imputation as with career earnings.

\section{Conclusion}

Our analysis of the mortality experience of participants in the HRS shows a strong pattern of increasing differential mortality in which life expectancy is rising for those at the top of the distribution of individuals ranked by alternative measures of socioeconomic status, but it is stagnate or declining for those at the bottom. The overall gains are most pronounced for men, for whom we compute a five-year average gain in life expectancy at age 55 between the 1920 and 1940 birth cohorts. The contrasting gain for women is less than one year. Differential mortality increases for both, however. For men, the gains are about two years for individuals in the $1^{\text {st }}$ decile of career earnings and six years for those at the top of the distribution. In contrast, life expectancy is declining for women in the lower deciles and rising by about two to three years for those at the top of the distribution.

These changes in mortality have significant effects on the distribution of lifetime social security benefits. For men, the differences in mortality offset about half of the progressivity in benefits elative to lifetime earnings. The implications are smaller for women, because they exhibit less of a change in life expectancy across the distribution of career earnings. Furthermore, while the increase in average life expectancy and the number of benefit years does raise the cost of the system as a whole, the current policy of raising the retirement age for everyone seems unfair to lower-income workers whose life expectancy may be constant or falling. 


\section{References}

Boies, John, Brian Rostron, and Elizabeth Arias. 2010. "Education Reporting and Classification On Death Certificates In The United States.” National Center for Health Statistics. Vital Health Stat 2 (151).

Congressional Budget Office. 2006. “Is Social Security Progressive.” Economic and Budget Issue Brief (December).

Coronado, Julia Lynn, Don Fullerton and Thomas Glass. 2000. “The Progressivity of Social Security.” NBER Working Paper 7520.

Cristia, Julian. 2009. "Rising mortality and life expectancy differentials by lifetime earnings in the United States.” Journal of Health Economics. 28: 984-995.

Duggan, James E., Robert Gillingham, and John S. Greenlees. 2007. "Mortality and Lifetime Income: Evidence from U.S. Social Security Records.” IMF Fiscal Affairs Department Working Paper.

Goda, Gopi Shah, John B. Shoven and Sita Nataraj Slavov. 2011. "Differential Mortality by Income and Social Security Progressivity." In David A. Wise, editor, Explorations in the Economics of Aging. Chicago: University of Chicago Press for NBER: 189-204.

Gustman, A. L., and T. L. Steinmeier. 2001. "How effective is redistribution under the Social Security Benefit Formula?” Journal of Public Economics 82 (Oct): 1-28.

Harris, Amy Rehder, and John Sabelhaus. 2005. “How Does Differential Mortality Affect Social Security Finances and Progressivity?” Congressional Budget Office (May) working paper.

Kitagawa, E.M. and P.M. Hauser. 1973. Differential Mortality in the United States: A Study in Socioeconomic Epidemiology. Cambridge, MA: Harvard University Press.

Liebman, Jeffrey B. 2002. “Redistribution in the Current U.S. Social Security System.” In Martin Feldstein and Jeffrey Liebman, editors, The Distributional Aspects of Social Security and Social Security Reform. Chicago: University of Chicago Press: 11-48.

Meara, Ellen, Seth Richards and David M. Cutler. 2008. “The Gap Gets Bigger: Changes in Mortality and Life Expectancy, by Education, 1981-2000.” Health Affairs (March) vol.27 no. 2: 350-360.

Oshansky, S. Jay, and others, 2012, "Differences in Life Expectancy Due to Race and Educational Differences Are Widening, and Many May Not Catch Up.” Health Affairs, 31, no.8 (2012):1803-1813. 
Pappas, Gregory, Susan Queen, Wilbur Hadden, and Gail Fisher. 1993. “The Increasing Disparity in Mortality between Socioeconomic Groups in the United States, 1960 and 1986." Vol. 329,2:103-109.

Preston, Samuel and Irma Elo. "Are Educational Differentials in Adult Mortality Increasing in the United States?” Journal of Aging and Health, 7: 476-96, 1995.

Smith, Karen, Eric Toder, and Howard Iams. 2003. Lifetime Distributional Effects of Social Security Retirement Benefits. Social Security Bulletin 65(1): 33-61

Social Security Administration. 2013. Annual Statistical Supplement to the Social Security Bulletin, 2012, table 5. A14.

Steuerle, Eugene, Lee Cohen, and Adam Carraso. 2004. "How Progressive is Social Security and Why" and "How Progressive is Social Security When Old Age and Disability Insurance Are Treated As a Whole?” Straight Talk on Social Security and Retirement Policy, Briefs 37 and 38.

Vallin J, Meslé F, and Valkonen T. (editors). 2001. Trends in Mortality and Differential Mortality. Council of Europe Publishing. Population Studies no 36

Waldron, Hillary. 2007. "Trends in Mortality Differentials and Life Expectancy for Male Social Security-Covered Workers, by Socioeconomic Status." Social Security Bulletin 67.3: 128.

Wilkins, Russell, Jean-Marie Berthelot, and Edward Ng. 2002. "Trends in Mortality by Neighborhood Income in Urban Canada from 1971 to 1996.” Supplement to Health Reports, Vol. 13, Statistics Canada. 
Table 1. Health and Retirement Study, Cohort Caracteristics

\begin{tabular}{|c|c|c|c|c|c|c|}
\hline Sample & $\begin{array}{l}\text { Ahead } \\
\text { (Aging and } \\
\text { Health } \\
\text { Dynamics) } \\
\end{array}$ & $\begin{array}{c}\text { CODA } \\
\text { (Children of } \\
\text { the } \\
\text { Depression) }\end{array}$ & $\begin{array}{c}\text { HRS } \\
\text { (Health and } \\
\text { Retirement } \\
\text { Survey) }\end{array}$ & $\begin{array}{c}\text { WB } \\
\text { (War Babies) }\end{array}$ & $\begin{array}{c}\text { EBB } \\
\text { (Early Baby } \\
\text { Boomers) }\end{array}$ & Total \\
\hline $\begin{array}{l}\text { Size of sample } \\
\text { Birth years }\end{array}$ & $\begin{array}{c}8,444 \\
\text { before } 1924\end{array}$ & $\begin{array}{c}2,420 \\
1924-1930\end{array}$ & $\begin{array}{c}13,525 \\
1931-1941\end{array}$ & $\begin{array}{c}2,760 \\
1942-1947\end{array}$ & $\begin{array}{c}3,522 \\
1948-1953\end{array}$ & 30,671 \\
\hline $\begin{array}{l}\text { Date of introduction } \\
\text { Percentage with }\end{array}$ & 1993 & 1998 & 1992 & 1998 & 2004 & $1992-200$ \\
\hline $\begin{array}{l}\text { earnings file } \\
\text { Percentage with }\end{array}$ & 45 & 70.0 & 79.2 & 69.7 & 56.7 & 65.7 \\
\hline $\begin{array}{l}\text { benefit file } \\
\text { Deaths }\end{array}$ & $\begin{array}{l}41.7 \\
5.846\end{array}$ & $\begin{array}{l}65.2 \\
863\end{array}$ & $\begin{array}{r}44.5 \\
2862\end{array}$ & $\begin{array}{c}30.4 \\
219\end{array}$ & 13.6 & $\begin{array}{c}40.5 \\
0.914\end{array}$ \\
\hline
\end{tabular}

Source: Calculated by the authors from the micro-data files of the HRS. Cases exclude those without earnings in the ages of 41-50, or whose only earnings years were within two years of death. Also, sample is limited to those with birth years from 1913 to 1960.

1. includes 110 individuals who were originally included with HRS. 
Table 2. Relative Rates of Mortality by Socioeconomic Status.

\begin{tabular}{|c|c|c|c|c|}
\hline \multirow[b]{3}{*}{ Group } & \multicolumn{4}{|c|}{ Relative Mortality } \\
\hline & \multicolumn{2}{|c|}{ Women } & \multicolumn{2}{|c|}{ Men } \\
\hline & $50-74$ & 75 \& over & $50-74$ & 75 \& over \\
\hline & \multicolumn{4}{|c|}{ Total Sample } \\
\hline Race & 129,300 & 57,593 & 99,409 & 37,487 \\
\hline Black & 1.55 & 1.05 & 1.31 & 1.19 \\
\hline Hispanic & 0.87 & 0.87 & 0.78 & 1.03 \\
\hline Other & 0.98 & 0.80 & 0.92 & 0.93 \\
\hline Non-hispanic whites & 0.89 & 1.01 & 0.97 & 0.97 \\
\hline Education & 129,204 & 57,591 & 99,198 & 37,421 \\
\hline Lt high-school & 1.59 & 1.24 & 1.38 & 1.21 \\
\hline High-school graduate & 0.92 & 0.87 & 0.99 & 0.97 \\
\hline Some college & 0.73 & 0.86 & 0.99 & 0.82 \\
\hline College and above & 0.54 & 0.79 & 0.57 & 0.74 \\
\hline Marital Status & 129,210 & 57,583 & 99,298 & 37,471 \\
\hline Married & 0.77 & 0.65 & 0.88 & 0.89 \\
\hline Never married & 1.29 & 1.13 & 1.30 & 1.25 \\
\hline Separated/divorced & 1.05 & 0.90 & 1.41 & 1.08 \\
\hline \multirow[t]{2}{*}{ Widowed } & 1.77 & 1.18 & 1.77 & 1.31 \\
\hline & \multicolumn{4}{|c|}{ Social Security Earnings Sample } \\
\hline \multicolumn{5}{|l|}{$\begin{array}{c}\text { Person earnings by } \\
\text { quintile }\end{array}$} \\
\hline 1 & 1.24 & 1.13 & 1.36 & 1.00 \\
\hline 2 & 1.17 & 1.00 & 1.16 & 1.28 \\
\hline 3 & 0.95 & 0.97 & 1.07 & 1.31 \\
\hline 4 & 0.90 & 0.95 & 1.02 & 0.66 \\
\hline 5 (top) & 0.80 & 0.84 & 0.57 & 0.35 \\
\hline \multicolumn{5}{|l|}{$\begin{array}{l}\text { Household career } \\
\text { earnings by quintile }\end{array}$} \\
\hline 1 & 1.47 & 1.23 & 1.29 & 1.07 \\
\hline 2 & 1.13 & 1.02 & 1.24 & 1.19 \\
\hline 3 & 1.02 & 0.99 & 1.10 & 0.80 \\
\hline 4 & 1.01 & 0.78 & 0.86 & 0.83 \\
\hline 5 (top) & 0.58 & 0.69 & 0.65 & 0.73 \\
\hline
\end{tabular}

Relative mortality is the mortality rate of the specific group divided by the average mortality rate for the category. Rates are based on annual observations over the interval of 1994 to 2009. 
Table 3. Logistic Estimates of 1-Year Mortality Rates, Health and Retirement Survey Respondents with earnings records

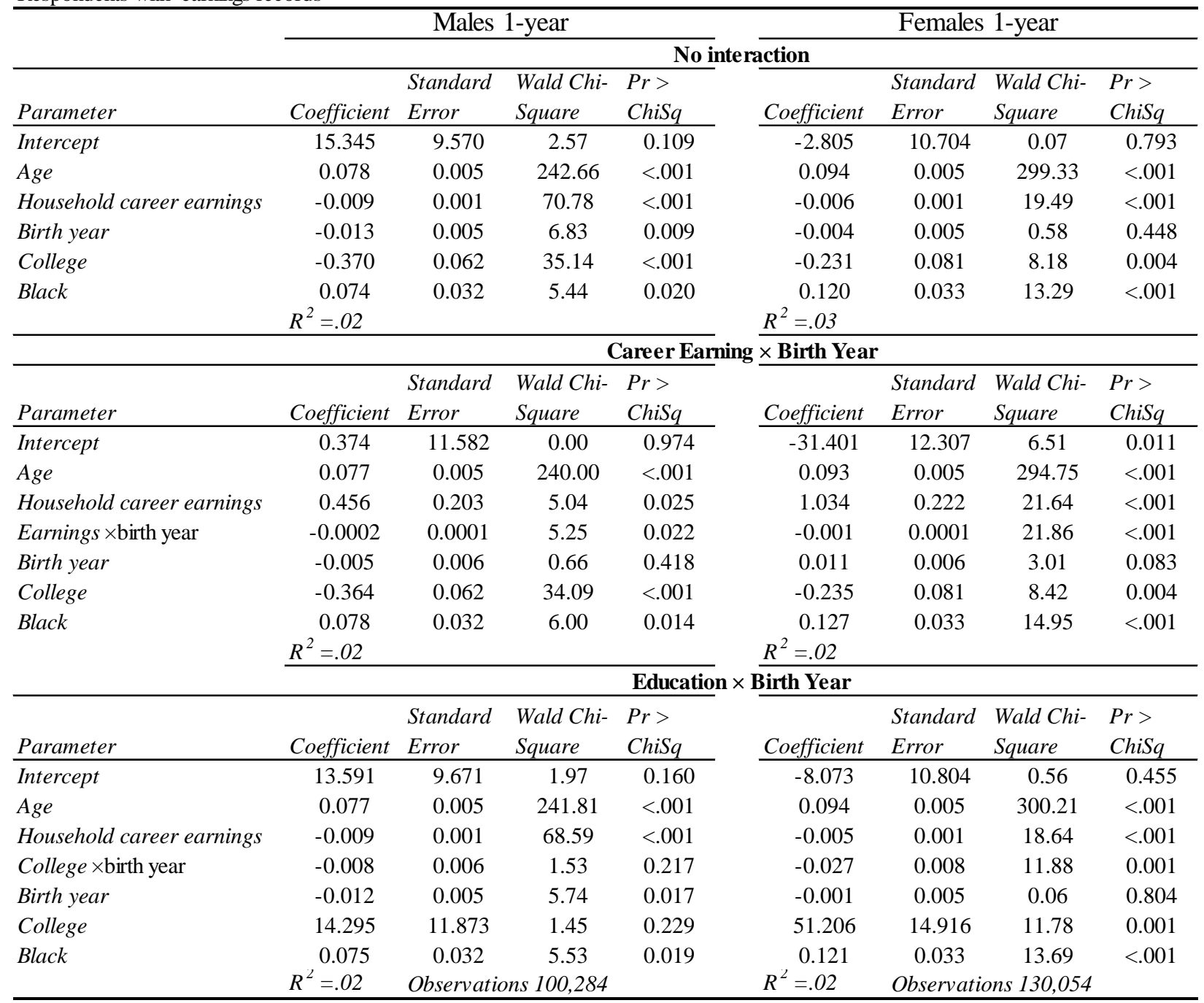

Source: HRS files for AHEAD, CODA, HRS, And EBB samples, waves 1992-2010. Career earnings are the average of nonzero earnings for ages 41-50 for each individual. Household career earnings for couples is the sum of individual career earnings divided by $\sqrt{ } 2$. 


\section{Table 4. Predictors of Career Earnings, Individuals}

Thousands of 2005 dollars

\begin{tabular}{|c|c|c|c|c|}
\hline \multirow[b]{2}{*}{ Coefficient } & \multicolumn{2}{|c|}{ Men } & \multicolumn{2}{|c|}{ Women } \\
\hline & Value & t-Value & Value & t-Value \\
\hline Intercept & -596.3 & -11.1 & -234.6 & -7.3 \\
\hline \multicolumn{5}{|l|}{ Education } \\
\hline$<$ high school & -21.8 & -25.4 & -18.2 & -30.0 \\
\hline high school graduate & -15.1 & -17.9 & -13.4 & -23.9 \\
\hline Some College & -13.1 & -14.4 & -9.1 & -15.0 \\
\hline College and Above & 0.0 & & 0.0 & \\
\hline Birth year & 0.3 & 12.1 & 0.1 & 8.5 \\
\hline \multicolumn{5}{|l|}{ Race } \\
\hline Black & -10.8 & -12.0 & -0.7 & -1.4 \\
\hline Hispanic & -15.2 & -13.5 & -4.2 & -5.8 \\
\hline Other & -14.2 & -6.7 & 0.1 & 0.1 \\
\hline White & 0.0 & & 0.0 & \\
\hline Never disabled & 9.8 & 8.3 & 2.8 & 3.9 \\
\hline \multicolumn{5}{|l|}{ Marital Status } \\
\hline Ever married/ widowed & 9.4 & 10.2 & -2.8 & -5.4 \\
\hline Never married & -8.4 & -4.8 & 6.4 & 6.0 \\
\hline separate/divorced & 0 & & 0 & \\
\hline $\mathrm{R}^{2}$ & 0.18 & & 0.14 & \\
\hline Oservations & 8,624 & & 9,503 & \\
\hline
\end{tabular}

Source: authors' regression estimates from the HRS micro-data files. 
Table 5. Logistic Estimates of Mortality Rates, Health and Retirement Survey

All respondents

\begin{tabular}{|c|c|c|c|c|c|c|c|c|}
\hline & \multicolumn{4}{|c|}{ Males 1-year } & \multicolumn{4}{|c|}{ Females 1-year } \\
\hline & \multicolumn{8}{|c|}{ No interaction } \\
\hline & & Standard & Wald Chi- & $\operatorname{Pr}>$ & & Standard & Wald Chi- & $\operatorname{Pr}>$ \\
\hline Parameter & Coefficient & Error & Square & ChiSq & Coefficient & Error & Square & ChiSq \\
\hline Intercept & 23.465 & 8.094 & 8.40 & 0.004 & -16.997 & 7.851 & 4.69 & 0.030 \\
\hline Age & 0.072 & 0.004 & 283.78 & $<.001$ & 0.096 & 0.004 & 553.90 & $<.001$ \\
\hline Household career earnings & -0.014 & 0.002 & 45.23 & $<.001$ & -0.011 & 0.001 & 65.04 & $<.001$ \\
\hline Birth year & -0.016 & 0.004 & 16.29 & $<.001$ & 0.003 & 0.004 & 0.72 & 0.398 \\
\hline College & -0.141 & 0.066 & 4.53 & 0.033 & -0.109 & 0.066 & 2.70 & 0.100 \\
\hline \multirow[t]{3}{*}{ Black } & 0.032 & 0.028 & 1.31 & 0.253 & 0.055 & 0.024 & 5.08 & 0.024 \\
\hline & $R^{2}=.02$ & & & & $R^{2}=.03$ & & & \\
\hline & \multicolumn{8}{|c|}{ Career Earning $\times$ Birth Year } \\
\hline Parameter & Coefficient & $\begin{array}{l}\text { Standard } \\
\text { Error }\end{array}$ & $\begin{array}{l}\text { Wald Chi- } \\
\text { Square }\end{array}$ & $\begin{array}{l}\mathrm{Pr}> \\
\text { ChiSq }\end{array}$ & Coefficient & $\begin{array}{l}\text { Standard } \\
\text { Error }\end{array}$ & $\begin{array}{l}\text { Wald Chi- } \\
\text { Square }\end{array}$ & $\begin{array}{l}\operatorname{Pr}> \\
\text { ChiSq }\end{array}$ \\
\hline Intercept & -16.897 & 13.471 & 1.57 & 0.210 & -45.355 & 9.460 & 22.98 & $<.001$ \\
\hline Age & 0.071 & 0.004 & 277.88 & $<.001$ & 0.094 & 0.004 & 533.52 & $<.001$ \\
\hline Household career earnings & 0.950 & 0.258 & 13.54 & 0.000 & 1.011 & 0.192 & 27.72 & $<.001$ \\
\hline Earnings $\times$ birth year & -0.001 & 0.0001 & 13.95 & 0.000 & -0.001 & 0.000 & 28.31 & $<.001$ \\
\hline Birth year & 0.005 & 0.007 & 0.44 & 0.505 & 0.018 & 0.005 & 14.27 & $<.001$ \\
\hline College & -0.146 & 0.066 & 4.81 & 0.028 & -0.106 & 0.066 & 2.58 & 0.108 \\
\hline \multirow[t]{3}{*}{ Black } & 0.038 & 0.028 & 1.76 & 0.185 & 0.053 & 0.024 & 4.74 & 0.030 \\
\hline & $R^{2}=.02$ & & & & $R^{2}=.03$ & & & \\
\hline & \multicolumn{8}{|c|}{ Education $\times$ Birth Year } \\
\hline Parameter & Coefficient & $\begin{array}{l}\text { Standard } \\
\text { Error }\end{array}$ & $\begin{array}{l}\text { Wald Chi- } \\
\text { Square }\end{array}$ & $\begin{array}{l}\operatorname{Pr}> \\
\text { ChiSq }\end{array}$ & Coefficient & $\begin{array}{l}\text { Standard } \\
\text { Error }\end{array}$ & $\begin{array}{l}\text { Wald Chi- } \\
\text { Square }\end{array}$ & $\begin{array}{l}\operatorname{Pr}> \\
\text { ChiSq }\end{array}$ \\
\hline Intercept & 19.774 & 8.174 & 5.85 & 0.016 & -20.599 & 7.904 & 6.79 & 0.009 \\
\hline Age & 0.072 & 0.004 & 282.47 & $<.001$ & 0.096 & 0.004 & 553.53 & $<.001$ \\
\hline Household career earnings & -0.014 & 0.002 & 45.00 & $<.001$ & -0.011 & 0.001 & 65.50 & $<.001$ \\
\hline College $\times$ birth year & -0.015 & 0.005 & 9.58 & 0.002 & -0.020 & 0.005 & 14.17 & $<.001$ \\
\hline Birth year & -0.015 & 0.004 & 12.42 & $<.001$ & 0.005 & 0.004 & 1.73 & 0.189 \\
\hline College & 28.959 & 9.400 & 9.49 & 0.002 & 38.101 & 10.147 & 14.10 & $<.001$ \\
\hline \multirow[t]{2}{*}{ Black } & 0.033 & 0.028 & 1.36 & 0.243 & 0.055 & 0.024 & 5.12 & 0.024 \\
\hline & $R^{2}=.02$ & Observatic & ns 125,1560 & & $R^{2}=.03$ & Observatic & ns 177,54 & \\
\hline
\end{tabular}

Source: HRS files for AHEAD, CODA, HRS, And EBB samples, waves 1992-2010. Career earnings are the average of earnings for ages 4150 for each individual. Household career eanings for couples is the sum of individual career earnings divided by $\sqrt{ } 2$. For observations without an earnings record, career earnings are predicted from the equation in table 4. 
Table 6. Distribution of Point-in-time and Lifetime Benefits by Earnings Decile

\begin{tabular}{|c|c|c|c|c|c|c|c|c|c|c|}
\hline \multirow{3}{*}{$\begin{array}{c}\text { Earning } \\
\text { deciles }\end{array}$} & \multicolumn{10}{|c|}{ Household-equivalized Earnings } \\
\hline & \multicolumn{5}{|c|}{ Males } & \multicolumn{5}{|c|}{ Females } \\
\hline & $\begin{array}{c}\mathrm{HH}- \\
\text { equivalized } \\
\text { earnings }\end{array}$ & $\begin{array}{l}\text { Annual } \\
\text { Benefit }\end{array}$ & $\begin{array}{l}\text { Lifetime } \\
\text { Benefit }\end{array}$ & $\begin{array}{l}\text { Survival } \\
\text { years at } \\
\text { age } 55\end{array}$ & $\begin{array}{l}\text { Benefit } \\
\text { years }\end{array}$ & $\begin{array}{c}\mathrm{HH}- \\
\text { equivalized } \\
\text { earnings }\end{array}$ & $\begin{array}{l}\text { Annual } \\
\text { Benefit }\end{array}$ & $\begin{array}{l}\text { Lifetime } \\
\text { Benefit }\end{array}$ & $\begin{array}{l}\text { Survival } \\
\text { years at } \\
\text { age } 55\end{array}$ & $\begin{array}{l}\text { Benefit } \\
\text { years }\end{array}$ \\
\hline 1 & 0.516 & 0.780 & 0.648 & 24.2 & 18.0 & 0.326 & 0.795 & 0.696 & 28.9 & 22.3 \\
\hline 2 & 0.723 & 0.890 & 0.769 & 25.7 & 18.9 & 0.453 & 0.890 & 0.796 & 29.2 & 22.8 \\
\hline 3 & 0.824 & 0.980 & 0.892 & 26.6 & 19.6 & 0.595 & 0.883 & 0.808 & 29.6 & 23.1 \\
\hline 4 & 0.901 & 0.991 & 0.935 & 27.3 & 20.5 & 0.788 & 0.894 & 0.860 & 30.4 & 23.9 \\
\hline 5 & 0.965 & 1.029 & 0.986 & 27.9 & 20.7 & 0.967 & 1.013 & 0.997 & 31.1 & 24.5 \\
\hline 6 & 1.027 & 1.032 & 1.030 & 28.8 & 21.4 & 1.103 & 1.046 & 1.057 & 31.6 & 25.0 \\
\hline 7 & 1.094 & 1.039 & 1.066 & 30.0 & 22.1 & 1.214 & 1.087 & 1.103 & 32.0 & 25.3 \\
\hline 8 & 1.178 & 1.031 & 1.120 & 30.9 & 23.0 & 1.327 & 1.092 & 1.134 & 32.3 & 25.4 \\
\hline 9 & 1.296 & 1.105 & 1.243 & 32.1 & 23.9 & 1.484 & 1.124 & 1.227 & 33.0 & 26.1 \\
\hline 10 & 1.476 & 1.123 & 1.312 & 34.3 & 25.0 & 1.742 & 1.176 & 1.323 & 34.3 & 26.8 \\
\hline \multirow[t]{2}{*}{ Average } & 48.914 & 11.859 & 257.595 & 28.8 & 21.3 & 40.510 & 11.184 & 283.743 & 31.2 & 24.5 \\
\hline & \multicolumn{10}{|c|}{ Individual-based Earnings } \\
\hline \multirow{2}{*}{$\begin{array}{l}\text { Earning } \\
\text { deciles }\end{array}$} & \multicolumn{5}{|c|}{ Males } & \multicolumn{5}{|c|}{ Females } \\
\hline & $\begin{array}{c}\mathrm{HH}- \\
\text { equivalized } \\
\text { earnings }\end{array}$ & $\begin{array}{l}\text { Annual } \\
\text { Benefit }\end{array}$ & $\begin{array}{l}\text { Lifetime } \\
\text { Benefit }\end{array}$ & $\begin{array}{l}\text { Survival } \\
\text { years }\end{array}$ & $\begin{array}{l}\text { Benefit } \\
\text { years }\end{array}$ & $\begin{array}{c}\mathrm{HH}- \\
\text { equivalized } \\
\text { earnings }\end{array}$ & $\begin{array}{l}\text { Annual } \\
\text { Benefit }\end{array}$ & $\begin{array}{l}\text { Lifetime } \\
\text { Benefit }\end{array}$ & $\begin{array}{l}\text { Survival } \\
\text { years }\end{array}$ & $\begin{array}{l}\text { Benefit } \\
\text { years }\end{array}$ \\
\hline 1 & 0.516 & 0.759 & 0.637 & 24.2 & 18.0 & 0.326 & 0.964 & 0.875 & 28.9 & 22.3 \\
\hline 2 & 0.723 & 0.866 & 0.759 & 25.7 & 18.9 & 0.453 & 1.077 & 1.000 & 29.2 & 22.8 \\
\hline 3 & 0.824 & 0.932 & 0.854 & 26.6 & 19.6 & 0.595 & 1.034 & 0.975 & 29.6 & 23.1 \\
\hline 4 & 0.901 & 0.973 & 0.924 & 27.3 & 20.5 & 0.788 & 0.962 & 0.939 & 30.4 & 23.9 \\
\hline 5 & 0.965 & 0.999 & 0.962 & 27.9 & 20.7 & 0.967 & 0.949 & 0.947 & 31.1 & 24.5 \\
\hline 6 & 1.027 & 1.043 & 1.035 & 28.8 & 21.4 & 1.103 & 0.937 & 0.954 & 31.6 & 25.0 \\
\hline 7 & 1.094 & 1.062 & 1.085 & 30.0 & 22.1 & 1.214 & 0.955 & 0.981 & 32.0 & 25.3 \\
\hline 8 & 1.178 & 1.078 & 1.149 & 30.9 & 23.0 & 1.327 & 1.005 & 1.042 & 32.3 & 25.4 \\
\hline 9 & 1.296 & 1.112 & 1.240 & 32.1 & 23.9 & 1.484 & 1.043 & 1.111 & 33.0 & 26.1 \\
\hline 10 & 1.476 & 1.176 & 1.355 & 34.3 & 25.0 & 1.742 & 1.074 & 1.176 & 34.3 & 26.8 \\
\hline Average & 48.914 & 12.142 & 260.965 & 28.8 & 21.3 & 40.510 & 9.125 & 223.572 & 31.2 & 24.5 \\
\hline
\end{tabular}

Source: Authors' calculations as described in text. The earnings and benefit values are expressed as a percent of the column average. Eqivalized earnings and beneftis use the combine total for couples divided by the square root of 2. 
Table 7. Distribution of Equivalized Benefits by Earnings Decile, 1920 and 1940 Birth Years

\begin{tabular}{|c|c|c|c|c|c|c|c|c|}
\hline \multicolumn{9}{|c|}{ Earnings-birth year iteraction for birth years of 1920 and 1940} \\
\hline \multirow{3}{*}{$\begin{array}{l}\text { Earning } \\
\text { deciles }\end{array}$} & \multicolumn{4}{|c|}{ Male Equivalized Benefits } & \multicolumn{4}{|c|}{ Female Equivalized Benefits } \\
\hline & \multicolumn{2}{|c|}{$\begin{array}{l}\text { Lifetime Benefit } \\
\text { (\% } 1920 \text { mean) }\end{array}$} & \multicolumn{2}{|c|}{$\begin{array}{c}\text { Number of Benefit } \\
\text { Years }\end{array}$} & \multicolumn{2}{|c|}{$\begin{array}{l}\text { Lifetime Benefit } \\
\text { (\% } 1920 \text { mean) }\end{array}$} & \multicolumn{2}{|c|}{$\begin{array}{c}\text { Number of Benefit } \\
\text { Years }\end{array}$} \\
\hline & 1920 & 1940 & 1920 & 1940 & 1920 & 1940 & 1920 & 1940 \\
\hline 1 & 68.8 & 75.5 & 16.6 & 18.2 & 71.1 & 64.4 & 21.2 & 19.2 \\
\hline 2 & 81.2 & 93.7 & 17.2 & 19.9 & 81.6 & 75.9 & 21.8 & 20.3 \\
\hline 3 & 93.3 & 109.9 & 17.8 & 21.0 & 82.4 & 78.7 & 22.0 & 21.1 \\
\hline 4 & 95.8 & 114.6 & 18.2 & 21.7 & 87.1 & 86.3 & 22.6 & 22.4 \\
\hline 5 & 99.9 & 121.1 & 18.2 & 22.0 & 99.9 & 101.9 & 22.9 & 23.4 \\
\hline 6 & 102.0 & 125.0 & 18.4 & 22.5 & 105.4 & 109.8 & 23.3 & 24.3 \\
\hline 7 & 102.5 & 127.2 & 18.5 & 22.9 & 109.7 & 116.2 & 23.5 & 24.9 \\
\hline 8 & 109.5 & 136.4 & 19.4 & 24.2 & 112.5 & 121.1 & 23.6 & 25.4 \\
\hline 9 & 121.8 & 152.9 & 20.3 & 25.5 & 120.7 & 132.5 & 24.0 & 26.3 \\
\hline 10 & 125.3 & 159.9 & 20.7 & 26.4 & 129.5 & 145.6 & 24.5 & 27.5 \\
\hline Average & 100.0 & 121.6 & 18.5 & 22.4 & 100.0 & 103.2 & 22.9 & 23.5 \\
\hline \multicolumn{9}{|c|}{ Education-birth year interaction for birth years of 1920 and 1940} \\
\hline \multirow{3}{*}{$\begin{array}{l}\text { Earning } \\
\text { deciles }\end{array}$} & \multicolumn{4}{|c|}{ Male Equivalized Benefits } & \multicolumn{4}{|c|}{ Female Equivalized Benefits } \\
\hline & \multicolumn{2}{|c|}{$\begin{array}{l}\text { Lifetime Benefit } \\
\text { (\% } 1920 \text { mean) }\end{array}$} & \multicolumn{2}{|c|}{$\begin{array}{c}\text { Number of Benefit } \\
\text { Years }\end{array}$} & \multicolumn{2}{|c|}{$\begin{array}{l}\text { Lifetime Benefit } \\
\text { (\% } 1920 \text { mean) }\end{array}$} & \multicolumn{2}{|c|}{$\begin{array}{c}\text { Number of Benefit } \\
\text { Years }\end{array}$} \\
\hline & 1920 & 1940 & 1920 & 1940 & 1920 & 1940 & 1920 & 1940 \\
\hline 1 & 66.7 & 77.9 & 17.4 & 20.4 & 68.5 & 65.6 & 22.1 & 21.2 \\
\hline 2 & 80.4 & 93.2 & 18.5 & 21.4 & 79.1 & 75.9 & 22.9 & 22.0 \\
\hline 3 & 93.1 & 107.5 & 19.2 & 22.2 & 80.5 & 77.4 & 23.4 & 22.5 \\
\hline 4 & 96.2 & 110.8 & 19.7 & 22.7 & 86.0 & 85.8 & 24.2 & 24.0 \\
\hline 5 & 100.9 & 116.0 & 19.9 & 22.8 & 99.6 & 97.5 & 24.8 & 24.3 \\
\hline 6 & 103.4 & 119.0 & 20.2 & 23.2 & 105.7 & 102.6 & 25.3 & 24.6 \\
\hline 7 & 104.4 & 120.3 & 20.3 & 23.4 & 110.6 & 107.2 & 25.7 & 24.9 \\
\hline 8 & 110.1 & 129.9 & 21.2 & 24.9 & 114.1 & 111.1 & 25.9 & 25.2 \\
\hline 9 & 120.5 & 147.5 & 21.8 & 26.6 & 123.0 & 122.7 & 26.5 & 26.4 \\
\hline 10 & 124.2 & 153.3 & 22.2 & 27.3 & 132.8 & 139.1 & 27.2 & 28.4 \\
\hline Average & 100.0 & 117.5 & 20.0 & 23.5 & 100.0 & 98.5 & 24.8 & 24.3 \\
\hline
\end{tabular}

Source: Authors' calculations as explained in text. The distribution of benefits for those born in 1920 and 1940 is expressed as a percentage of the mean benefit for the 1920 cohort. Equivalized benefits are based on the combined benefit for couples divided by the square root of 2 . 
Figure 1. Distribution of Earnings, Annual Benefits, and Lifetime Benefits by Income Decile
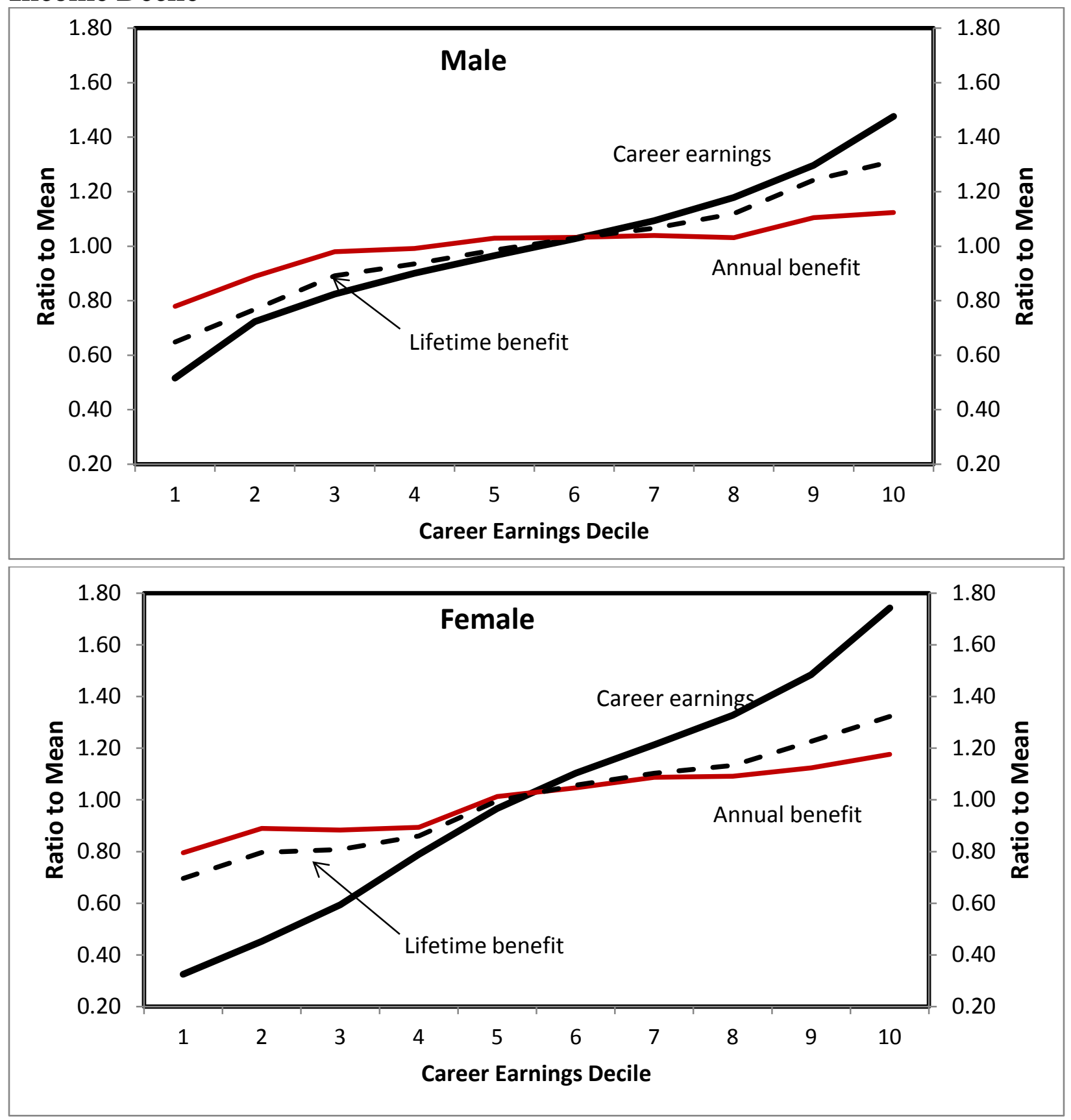

Source: Table 6, household equivalized benefits 
Figure 2. Distribution of Lifetime Benefits, 1920 and 1940 Birth Cohorts

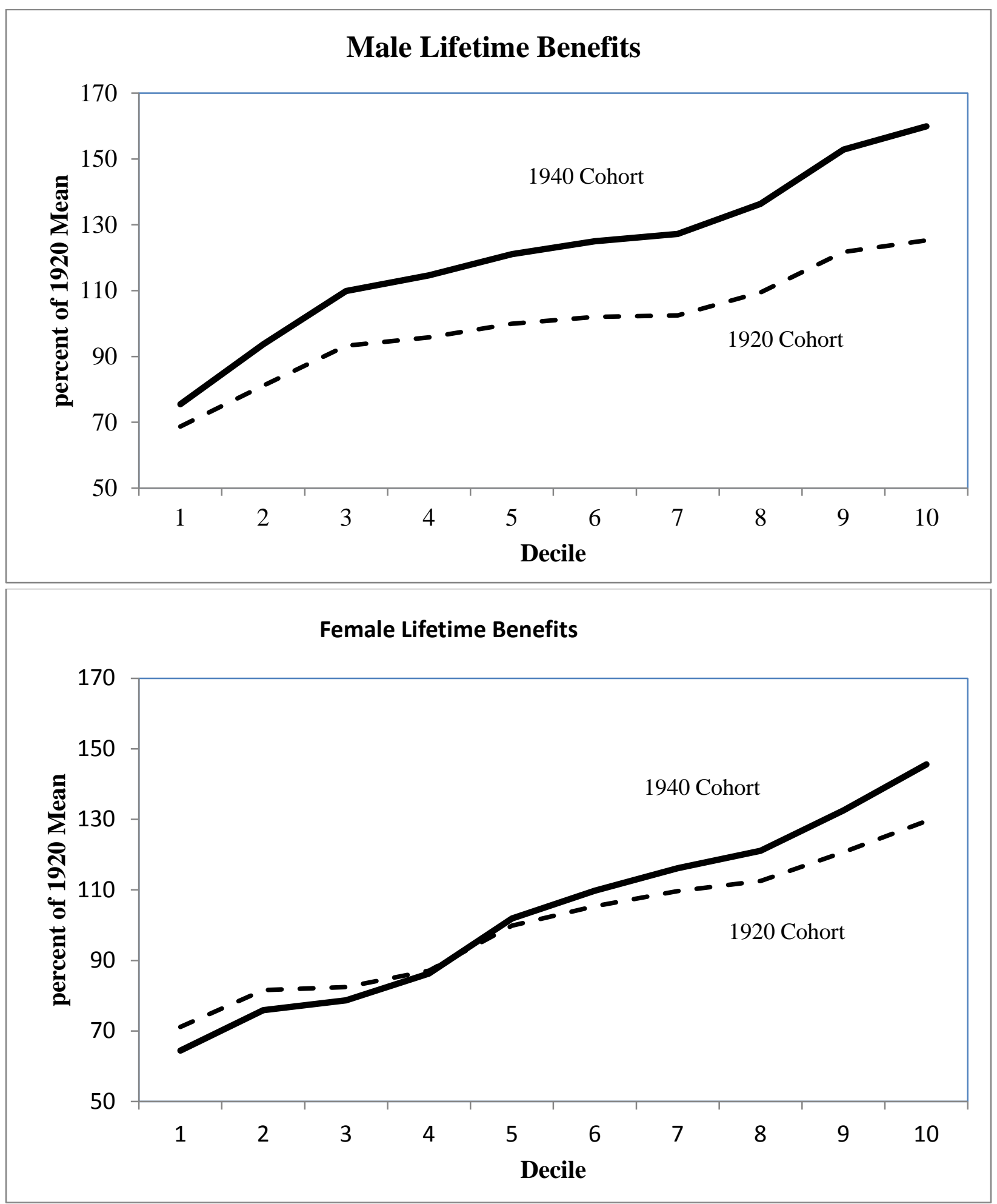

Source: Table 7, Household equivalized benefits 


\section{RECENT WORKING PAPERS FROM THE CENTER FOR RETIREMENT RESEARCH AT BOSTON COLLEGE}

Adding Employer Contributions to Health Insurance To Social Security's Earnings and Tax Base

Karen E. Smith and Eric Toder, April 2014

Lower-Income Individuals Without Pensions: Who Misses Out and Why?

April Yanyuan Wu and Matthew S. Rutledge, March 2014

How Do Subjective Longevity Expectations Influence Retirement Plans?

Mashfiqur R. Khan, Matthew S. Rutledge, and April Yanyuan Wu, January 2014

Impact of the Great Recession on Retirement Trends in Industrialized Countries Gary Burtless and Barry P. Bosworth, December 2013

Does Household Debt Influence the Labor Supply and Benefit Claiming Decisions of Older Americans?

Barbara A. Butrica and Nadia S. Karamcheva, December 2013

Point of No Return: How Do Financial Resources Affect the Timing of Retirement After a Job Separation?

Matthew S. Rutledge, December 2013

The Medicaid Buy-In and Social Security Disability Insurance (DI) Beneficiaries: Lessons for the 2014 Medicaid Expansion and Proposals to Reform DI

Melissa McInerney, December 2013

Validating Longitudinal Earnings in Dynamic Microsimulation Models: The Role of Outliers

Melissa M. Favreault and Owen Haaga, September 2013

Housing in Retirement Across Countries

Makoto Nakajima and Irina A. Telyukova, August 2013

Can Benefits and Work Incentives Counseling Be a Path to Future Economic SelfSufficiency for SSI/SSDI Beneficiaries?

Zafar E. Nazarov, August 2013

How Do the Changing Labor Supply Behavior and Marriage Patterns of Women Affect Social Security Replacement Rates?

April Yanyuan Wu, Nadia S. Karamcheva, Alicia H. Munnell, Patrick Purcell, July 2013

All working papers are available on the Center for Retirement Research website (http://crr.bc.edu) and can be requested by e-mail (crr@bc.edu) or phone (617-552-1762). 